\title{
Changes in resistance percentage to antibiotics in Pseudomonas aeruginosa and Acinetobacter baumannii strains isolated from blood cultures of intensive care unit patients
}

\section{Yoğun bakım hastalarının kan kültürlerinden izole edilen Pseudomonas aeruginosa ve Acinetobacter baumannii izolatlarının antibiyotik direnç yưizdelerindeki değișim}

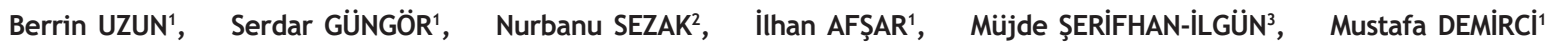

\section{ÖZET}

Amaç: Pseudomonas aeruginosa ve Acinetobacter baumannii enfeksiyonları özellikle yoğun bakım ünitesinde (YBÜ) yatan hastalar için en önemli sorunlardan birisidir. Bu çalıșmanın amacı, YBÜ hastalarında kan dolaşımı enfeksiyonlarına sebep olan $P$. aeruginosa ve A. baumanni etkenlerinin antimikrobiyal direnç paternlerini belirlemek ve ampirik tedavi protokollerinin uygunluğunu değerlendirmektir.

Yöntemler: Ocak-Aralık 2010 ve Ocak-Aralık 2011 tarihlerinde YBÜ'de yatan hastalara ait hemokültür örneklerinde üreyen suşların direnç oranları ayrı ayrı incelenerek karșılaștırıldı. Bu iki zaman aralığı arasında direnç oranlarındaki farklılıklar karşılaştırılarak istatistiksel olarak analiz edildi.

Bulgular: $P$. aeruginosa sușlarının piperasilintazobaktam, sefaperazon - sulbaktam, seftazidim, siprofloksasin, gentamisin, amikasin ve netilmisine direnç oranlarında 2011 yılında 2010 yılına oranla azalma olduğu saptandı ( $p$ değerleri sırasıyla, 0,0059, $0,0000,0,0048,0,0350,0,0000,0,0000,0,0003)$. Buna karșılık, aztreonam direnç oranında artış saptandı ( $p$ değeri, 0,0155). İmipenem direncinin benzer oranlarda

\section{ABSTRACT}

Objective: Infections of Pseudomonas aeruginosa and Acinetobacter baumannii are one of the greatest concerns for hospitalized patients, particularly those in intensive care units (ICUs). The aim of this study was to determine the antimicrobial resistance percentages and to assess empirical treatment options for bloodstream infections due to $P$. aeruginosa and $A$. baumannii strains in ICU patients.

Methods: Resistance percentages of strains isolated in January- December 2010 and January- December 2011 were separately analyzed and compared. The differences in resistance percentages between two intervals was statistically analyzed.

Results: A statistically significant decrease was found in the resistance percentage of piperacillin-tazobactam, cefoperazone-sulbactam, ceftazidime, ciprofloxacin, gentamicin, amikacin and netilmicin in the second period compared with the first ( $\mathrm{p}$ values were $0.0059,0.0000$, $0.0048,0.00350,0.0000,0.0000,0.0003$, respectively) for $P$. aeruginosa strains. Whereas resistance percentage of aztreonam was increased ( $p$ value was 0.0155). Resistance percentage of imipenem was found similar.

İzmir Katip Çelebi Üniversitesi, Atatürk Eğitim ve Araştırma Hastanesi, Tıbbi Mikrobiyoloji Laboratuarı, IZMiR

2 İzmir Katip Çelebi Üniversitesi, Atatürk Eğitim ve Araştırma Hastanesi, İntaniye Kliniği, IZMIR

3 Turgutlu Toplum Sağlığı Merkezi, Halk Sağlığı, IZMiR

İletişim/Corresponding Author : Berrin UZUN

İzmir Katip Çelebi Üni., Atatürk Eğitim ve Araştırma Hast., Tıbbi Mikrobiyoloji Lab., İZMiR

Tel : +90232 $2444444-1982$

E-posta / E-mail : berrinuzun@gmail.com

DOI ID : 10.5505/TurkHijyen.2014.68916

Uzun B, Güngör S, Sezak N, Afșar I, Șerifhan-illgün M, Demirci M. Yoğun bakım hastalarının kan kültürlerinden izole edilen Pseudomonas aeruginosa ve Acinetobacter baumannii izolatlarının antibiyotik direnç yüzdelerindeki değișim. Turk Hij Den Biyol Derg, 2014; $71(1)$ : 1-8. 
olduğu görüldü. $A$. baumannii suşlarının sefepim ve amikasin direnç oranlarında ikinci periyotta ilkine oranla istatistiksel olarak anlamlı azalma saptandı ( $p$ değerleri, 0,0003 ve 0,0000). Ampisilin-sulbaktam, piperasilintazobaktam ve imipeneme karșı direnç oranlarında artış saptandı ( $p$ değerleri sırasıyla, 0,0003, 0,0210, 0,0033). Her iki bakteri türünde de kolistine direnç saptanmadı. A. baumannii izolatlarında tigesiklin direnci saptanmadi.

Sonuç: Her hastanenin özellikle yoğun bakım birimlerinden izole edilen sușların antibiyotik direnç paternlerinin aktif sürveyansla takibi, ampirik tedavi yaklașımlarını belirlemeye hizmet eder. Bu çalıșmada antibiyotik kullanım politikasının hastane enfeksiyonları ile mücadelede önemli bir adım olduğu vurgulanmıștır. Sonuç olarak, direnç oranlarını azaltmak için, enfeksiyon kontrol önlemleri alınmalı, ampirik tedavi rejimleri sürekli gözden geçirilmeli ve aktif surveyans verilerine göre belirlenmelidir.

Anahtar Sözcükler: Acinetobacter baumannii, Pseudomonas aeruginosa, antibiyotik direnci, kan kültürü, yoğun bakım ünitesi

\section{INTRODUCTION}

Nosocomial infections pose a threat in difficult to treat patients, especially in the high-risk departments such as Intensive Care Units (ICUs) (1). Bloodstream infections are being reported as a leading cause of morbidity and mortality worldwide. Moreover, bloodstream infections represent about $15 \%$ of all nosocomial infections and causes of health care costs $(2,3)$.

Pseudomonas aeruginosa and Acinetobacter baumannii are nonfermentative gram-negative bacteria that have minimal nutritional requirements and can survive on a wide variety of surfaces and in aqueous environments. Infections with $P$. aeruginosa or $A$. baumannii are of greatest concern for hospitalized patients, particularly those in ICUs, where these opportunistic pathogens are capable of developing severe invasive infections in critically ill and immunocompromised patients (4). In recent
In A.baumannii strains, a statistically significant decrease was found in resistance percentage of cefepime and amikacin in the second period compared with the first ( $p$ values were $0.0003,0.0000$ ). Resistance percentage of ampicillin-sulbactam, piperacillin-tazobactam and imipenem was increased ( $p$ values were $0.0003,0.0210$, 0.0033 ). There was no colistin resistance determined in both species. Tigecycline resistance was not found in $A$. baumannii isolates.

Conclusion: Active surveillance of antibiotic resistance percentages of isolated strains especially in ICUs serves to determine empirical treatment regimens in every institution. The present study emphasized that antibiotic usage policy is an important step to combat hospital infections. Consequently, infection control measures should be taken, empirical treatment regimens should be constantly reviewed, and should be determined according to active surveillance data in order to decrease resistance percentages.

Key Words: Acinetobacter baumannii, Pseudomonas aeruginosa, Antibiotic resistance, Blood culture, Intensive care unit

years, multiple antimicrobial resistance patterns of these bacteria have become as a major problem and a factor that complicates the treatment (5). Uncontrolled and intensive use of antimicrobials is one of the most important reasons for the increase of resistant strains. Each hospital should have data about their antimicrobial susceptibility patterns of nonfermentative bacteria to choose appropriate empirical treatment regimens for reducing morbidity and mortality. To have data about resistance percentage is required not only for assessment of treatment options but also to monitor the spread of resistant organisms or resistance genes throughout the hospital and community. Therefore each hospital must regularly follow their isolates, determine resistance percentage of antibiotics and regulate their own empirical treatment protocols according to these results (6). The present study was designed for this aim. 


\section{MATERIAL AND METHODS}

The study was performed retrospectively in an 1100-bed tertiary training hospital at the western part of Turkey. ICU bed ratio was 7\% of all bed capacity. P. aeruginosa and $A$. baumannii which was isolated from blood cultures of ICU patients between January 2010 and December 2011 was examined. All results evaluated in 2 periods (first period January -December 2010, second period January- December 2011). Totally 470 strains included in the study 157 (33.4\%) P. aeruginosa and 313 (66.6\%) A. baumannii strains). In the first period, 84 (36\%) P. aeruginosa and $152(64 \%) A$. baumanni and in the second period 73 (31\%) P. aeruginosa and 161 (69\%) A. baumannii strains were evaluated.

Automated blood culture system (Bactec $9240^{\mathrm{TM}}$, Becton-Dickinson Diagnostic Instrument Systems, USA) was used for isolation of bacterial strains from blood specimens. Identification was performed based on conventional methods. Confirmation and antimicrobial resistance results of the isolated strains to 16 antibacterial agents was made by automated system (BD Phoenix $100^{\text {TM }}$ System, Beckton Dickinson, USA). Antimicrobials tested for $P$. aeruginosa was piperacillin-tazobactam, ceftazidime, cefepime, imipenem, aztreonam, gentamicin, amikacin, netilmicin, ciprofloxacin, and colistin, for $A$. baumanni was ampicillin-sulbactam, piperacillin-tazobactam, cefotaxime, ceftriaxone, ceftazidime, cefepime, imipenem, gentamicin, amikacin, ciprofloxacin, tigecycline, trimetoprim-sulfamethoxazole, and colistin. Antimicrobial susceptibility of the isolated strains was determined using Kirby-Bauer Disk diffusion method for cefoperazone-sulbactam. All studies performed according to the CLSI standards (7). Zone diameter of cefoperazone was used for cefoperazone-sulbactam whose limit values are not standard approved by CLSI. Tigecycline breakpoints approved by the US Food and Drug Administration (FDA) for indicated Enterobacteriaceae species was applied for comparison purposes. Moderately susceptible strains were accepted as resistant (8). $P$. aeruginosa ATCC 27853 was used as quality control strain.

Differences in resistance percentage to antibiotics between these two periods was analyzed. Statistical analyses was performed by using Epi İnfo version 7 program (CDC, Atlanta). Chi-square test was applied where appropriate. For all analyses, a P value of less than 0.05 was considered statistically significant.

\section{RESULTS}

A statistically significant decrease was found in resistance percentage of piperacillin-tazobactam, cefoperazone-sulbactam, ceftazidime, netilmicin, amikacin, gentamicin, and ciprofloxacin in the second period compared with the first ( $\mathrm{p}$ values were 0.0059 , $0.0000,0.0048,0.0003,0.0000,0.0000$ and 0.0350 , respectively) for $P$. aeruginosa strains. Whereas resistance percentage of aztreonam was increased. This result was also statistically significant ( $p$ value was 0.0155 ). Resistance percentage of cefepime and imipenem was also slightly decreased but this result was statistically insignificant. Colistin resistance was not found in both periods. The antimicrobial resistance percentage of the $P$. aeruginosa strains in both periods was listed in Table 1.

In $A$. baumannii strains, a statistically significant decrease was found in resistance percentage of cefepime, and amikacin in the second period compared with the first one ( $p$ values were 0.0003 and 0.0000 , respectively). In contrast resistance percentage of ampicillin-sulbactam, piperacillintazobactam, and imipenem was increased ( $p$ values were $0.0003,0.0210,0.0033$, respectively). Changes in resistance percentage of cefoperazone-sulbactam, ceftazidime, gentamicin, and ciprofloxacin were statistically insignificant. The resistance percentages of cefotaxime, ceftriaxone and trimetoprimsulfamethoxazole for $A$. baumannii isolates were $\% 100$ in first period and $97 \%, 97 \%$ and $95 \%$, respectively in 
the second period. Colistin and tigecycline resistance resistance percentages of the $A$. baumannii isolates was not found in both periods. The antimicrobial in both periods was listed in Table 2.

Table 1. The antimicrobial resistance profiles of the $P$. aeruginosa isolates

\begin{tabular}{|c|c|c|c|c|c|c|}
\hline \multirow{3}{*}{ Antimicrobials } & \multicolumn{4}{|c|}{ Pseudomonas spp. } & \multirow{3}{*}{$\mathbf{P}$} & \multirow{3}{*}{$\mathrm{X}^{2}$} \\
\hline & \multicolumn{2}{|c|}{2010} & \multicolumn{2}{|c|}{2011} & & \\
\hline & $\mathrm{n}$ & $(\%)$ & $\mathrm{n}$ & $(\%)$ & & \\
\hline Piperacillin-Tazobactam & 53 & 63 & 30 & 41 & $0,0059^{*}$ & 7,5860 \\
\hline Cefoperazone-sulbactam & 59 & 70 & 26 & 36 & $0,0000^{*}$ & 18,8558 \\
\hline Ceftazidime & 50 & 60 & 27 & 37 & $0,0048^{*}$ & 7,9384 \\
\hline Cefepime & 55 & 66 & 37 & 51 & 0,0606 & 3,5222 \\
\hline İmipenem & 16 & 19 & 13 & 18 & 0,8418 & 0,0398 \\
\hline Aztreonam & 62 & 74 & 65 & 89 & $0,0155^{*}$ & 5,8623 \\
\hline Gentamicin & 67 & 80 & 17 & 23 & $0,0000^{*}$ & 50,0726 \\
\hline Amikacin & 35 & 42 & 9 & 12 & $0,0000^{*}$ & 16,6659 \\
\hline Netilmicin & 33 & 39 & 8 & 11 & $0,0003^{*}$ & 12,8579 \\
\hline Ciprofloxacin & 44 & 52 & 26 & 36 & $0,0350^{*}$ & 4,429 \\
\hline Colistin & 0 & 0 & 0 & 0 & - & - \\
\hline Totally tested isolates & 84 & 100 & 73 & 100 & - & - \\
\hline
\end{tabular}

* $P$ values as statistically significant

Table 2. The antimicrobial resistance profiles of the $A$. baumannii isolates

\begin{tabular}{|c|c|c|c|c|c|c|}
\hline \multirow{3}{*}{ Antimicrobials } & \multicolumn{4}{|c|}{ Acinetobacter spp. } & \multirow{3}{*}{$\mathbf{P}$} & \multirow{3}{*}{$x^{2}$} \\
\hline & \multicolumn{2}{|c|}{2010} & \multicolumn{2}{|c|}{2011} & & \\
\hline & $\mathrm{n}$ & $(\%)$ & $\mathrm{n}$ & $(\%)$ & & \\
\hline Sulbactam-Ampicillin & 140 & 92 & 161 & 100 & $0,0003^{*}$ & 13,2173 \\
\hline Piperacillin-Tazobactam & 132 & 87 & 152 & 94 & $0,0210^{*}$ & 5,3265 \\
\hline Cefoperazone-sulbactam & 82 & 54 & 91 & 57 & 0,6471 & 0,2096 \\
\hline Cefotaksime & 152 & 100 & 156 & 97 & - & - \\
\hline Ceftriaxone & 152 & 100 & 156 & 97 & - & - \\
\hline Ceftazidime & 147 & 97 & 152 & 94 & 0,3251 & 0,9685 \\
\hline Cefepime & 152 & 100 & 148 & 92 & $0,0003^{*}$ & 12,8051 \\
\hline İmipenem & 111 & 73 & 139 & 86 & $0,0033^{*}$ & 8,6145 \\
\hline Gentamicin & 146 & 96 & 149 & 93 & 0,1830 & 1,7732 \\
\hline Amikacin & 88 & 58 & 51 & 32 & $0,0000^{*}$ & 21,7691 \\
\hline Ciprofloxasin & 124 & 82 & 131 & 81 & 0,9614 & 0,0023 \\
\hline Tigecycline & 0 & 0 & 0 & 0 & - & - \\
\hline Trimetoprim-Sulfamethoxazole & 152 & 100 & 153 & 95 & - & - \\
\hline Colistin & 0 & 0 & 0 & 0 & - & - \\
\hline Totally tested isolates & 152 & 100 & 161 & 100 & - & - \\
\hline
\end{tabular}

${ }^{*} P$ values as statistically significant 


\section{DISCUSSION}

Hospital-acquired Pseudomonas species and Acinetobacter species are frequently resistant to a broad range of antibiotics. Pseudomonas spp. is intrinsically resistant to most antibiotics. Antimicrobial resistance develops rapidly under antimicrobial selection pressure, and multiple mechanisms are responsible such as hyper-production of enzymes, beta-lactamases and DNA-gyrases, active efflux pumps and permeability changes. Besides, multi-drug resistant and pan-drug resistant A. baumannii strains becomes an important problem in many hospital (9).

Resistance percentage can be reduced through effective antibiotic use policies and infection control measures. The present study demonstrated that colistin, imipenem and aminoglycosides was the most effective agents to $P$. aeruginosa strains, tigecycline and colistin were the most effective agents to $A$. baumannii. Currently, a limited number of broadspectrum antimicrobials are available to combat multidrug-resistant organisms (10). Tigecycline is one of these agents. Different results were reported in studies conducted with tigecycline. It was reported that resistance percentage of $A$. baumannii strains against tigecycline was $7-78 \%(11,12,13)$. In the current study, resistance was not detected in A. baumannii strains. This variability in results may be due to geographical differences.

Colistin was reported as the most effective antibiotic in many studies to $P$. aeruginosa and $A$. baumannii strains similar to the present study. Colistin, a polymyxin (polymyxin E) was known from the 1960s, its systemic usage has been limited due to toxic effects such as nephrotoxicity, and neurotoxicity (14). Usage of colistin has come raised again due to nosocomial infections of multidrug-resistant nonfermentative gram-negative bacteria.

In the present study, althought imipenem was found one of the most effective agent againts $P$. aeruginosa isolates, decreased activity was found against $A$. baumannii isolates. Increase in resistance of imipenem has been found statistically significant especially in $A$. baumannii strains. In the report of European MYSTIC study group, the highest percentage of resistance to imipenem reported from Turkey (15). In some studies, imipenem and meropenem were the most effective agent against the nonfermenters $(16,18,20)$. In a different study, resistance percentage of meropenem and imipenem were $16-54.3 \%$ for A. baumannii strains and $15-29 \%$ for $P$. aeruginosa strains $(17,19)$. Consequently, carbapenems remain the most effective agents despite the increasing resistance percentages. The current study has shown that imipenem is still a good option for $P$. aeruginosa strains but resistance percentage of $A$. baumannii strains are increasing. In this study, the lack of data about carbapenems such as meropenem and doripenem is a major shortcoming.

It is reported that the combination of meropenem and aminoglycoside is effective against almost all $P$. aeruginosa strains which included meropenemresistant strains (21). According to the results of this study aminoglycoside is one of the most effective antibiotics and resistance percentages were decreased. Iseri et al was found that the resistance of amikacin decreased for $P$. aeruginosa isolates in four years period (22). Surveillance studies reported that resistance percentage of amikacin for $P$. aeruginosa was $2.6 \%$ in Canada (23), 10\% in Belgium (24), and the Grand Duchy of Luxembourg and 4\% in USA (25). SENTRY study determined that the most potent antibiotic was amikacin against Pseudomonas strains (18).

Resistance percentage of sulbactam-ampicilin and piperacillin-tazobactam was also increased like resistance percentage of imipenem against A. baumannii strains. This increase may result due to intensive use of beta lactam and beta lactamases combinations for treatment in our hospital. Cefoperazone-sulbactam is a preferred drug especially in the treatment of Acinetobacter 
spp. infections but bacteria has become resistant to this drug over the years (26). Unlike our results, piperacillin-tazobactam was the most effective antipseudomonal drug in HITIT-2 and SENTRY studies $(16,18)$. Resistance percentage of piperacillintazobactam was reported $9.3 \%$ in Canada, $16 \%$ in USA, and $17.8 \%$ in Belgium (23-25). A. baumannii isolates was highly resistant to many of the antimicrobial agents but the lowest percentage of resistance was observed against cefoperazone-sulbactam (52\%) in HITIT-2 (16). But resistance percentage was reported $21 \%-70 \%$ in various studies (27-29). Cefoperazonesulbactam is not included in the CLSI interpretive criteria. Therefore, it should not be ignored that the amount and percentage of cefoperazone and sulbactam in antibiogram disk becomes unacceptable to resistance detection and gave the wrong sensitivity to an extent that was not be accepted (27).

Ciprofloxacin may be a good option due to low toxicity. In our study, resistance percentage of ciprofloxacin was decreased in $P$. aeruginosa and it is statistically significant. Ciprofloxacin resistance percentage was reported $24 \%$ by Eldere et al, $32 \%$ by Cavallo et al, and $41 \%$ by Landman et al for
P. aeruginosa strains $(24,25,30)$. Iseri et al found that the resistance of ciprofloxacin increased for $P$. aeruginosa isolates in four years period (22).

Conclusion, extensive and uncontrolled use of antibiotics in ICU patients generally results with increase of resistance percentages to antibiotics. That is why rational use of antibiotics and sharing data of resistance percentages with physicians is essential. Regular surveillance of antibiotics resistance percentages serves to determine empirical treatment regimens in every institution. These results should be taken into consideration to determine antibiotic use policy in hospital. Higher resistance percentages of imipenem, sulbactam and piperacillin-tazobactam against Acinetobacter spp strains is still an important issue in our institution. New measures should apply to improve this situation.

Briefly, infection control measures should be taken, empirical treatment regimens should be constantly reviewed, and empirical treatment approaches should be determined according to active surveillance data in order to decrease resistance percentages.

\section{REFERENCES}

1. Ding JG, Sun QF, Li KC, Zheng $M H$, Miao XH, Ni $W$ et al. Retrospective analy $\neg$ sis of nosocomial infections in the intensive care unit of a tertiary hospital in China during 2003 and 2007. BMC Infect Dis, 2009; 9: 115.

2. Saghir S, Faiz M, Saleem M, Younus A, Aziz H. Characterization and anti - microbial susceptibility of gram-negative bacteria isolated from bloodstream infections of cancer patients on chemotherapy in Pakistan. Indian J Med Microbiol, 2009; 27: 341-7.
3. Vitkauskienė A, Skrodenienè E, Dambrauskienè A, Macas A, Sakalauskas R. Pseudomonas aeruginosa bacteremia: resistance to antibiotics, risk factors, and patient mortality. Medicina (Kaunas), 2010; 46(7): 490-5.

4. Karlowsky JA, Draghi DC, Jones ME, Thornsberry C, Friedland IR, Sham DF. Surveillance for antimicrobial susceptibility among clinical isolates of Pseudomonas aeruginosa and Acinetobacter baumannii from hospitalized patients in the United States, 1998 to 2001. Antimicrobial Agents and Chemotherapy, 2003; 47(5): 1681-8. 
5. Gazi H, Tünger O, Vural S, Ozbakkaloglu B, Sürücüoglu S. In vitro activities of various antibiotic combinations on multiresistant Acinetobacter baumannii strains. J Turk Microbiol Soc, 2007; 37(1): 11-4.

6. Micek ST, Lloyd AE, Ritchie DJ, Reichley RM, Fraser VJ, Kollef MH. Pseudomonas aeruginosa Bloodstream Infection: Importance of Appropriate Initial Antimicrobial Treatment. Antimicrob Agents Chemother, 2005; 49 (4): 1306-11.

7. Clinical and Laboratory Standards Institute (CLSI). Performance standards for antimicrobial susceptibility testing. 20th Informational Supplement, M100-S20, CLSI, Wayne, PA. 2010

8. Karageorgopoulos DE, Kelesidis T, Falagas ME. Tigecycline for the treatment of multidrugresistant (including carbapenem-resistant) Acinetobacter infections: a review of the scientific evidence. J Antimicrob Chemother, 2008; 62(5): 45-55.

9. Brusselaers N, Vogelaers D, Blo S. The rising problem of antimicrobial resistance in the intensive care unit. Ann Intensive Care, 2011; 1: 47.

10. Rose WE, Rybak M J. Tigecycline: First of a new class of antimicrobial agents. Pharmacotherapy 2006; 26: 1099-110.

11. Zer $Y$, Akın FEO, Namıduru M. The antibacterial activitiy of tigecycline on Acinetobacter baumannii strains. Turkish J Infect, 2007; 21(4): 193-6.

12. Pachon Ibanez ME, Jimenez Mejias ME, Pichardo C, Llanos AC, Pachon J. Activity of tigecyline (GAR936) against Acinetobacter baumannii strains, including those resistant to imipenem. Antimicrob Agent Chemother, 2004; 48(11): 4479-81.

13. Navon Venezia S, Leavitt A, Carmeli Y. High tigecycline resistance in multidrug-resistant Acinetobacter baumannii. J Antimicrob Chemother, 2007; 59(4): 772-4.

14. Azap OK, Arslan H, Ergin F, Inci EK, Yapar Y. In vitro activity of colistin against nonfermentative gram-negative bacilli. J Ankara Uni Fac Med, 2005; 58(2): 65-67.

15. Goossens H. Susceptibility of multidrug-resistant Pseudomonas aeruginosa in intensive care units: results from the European MYSTIC study group. Clin Microbiol Infect, 2003; 9(9): 980-3.
16. Gür D, Hascelik G, Aydin N, Telli M, Gültekin M, Ogülnç $D$ et al. Antimicrobial resistance in gramnegative hospital isolates: Results of the Turkish HITIT-2 Surveillance Study of 2007. J Chemother, 2009; 21(4):383-9.

17. Turner PJ. MYSTIC Europe 2007: activity of meropenem and other broad-spectrum agents against nosocomial isolates. Diagn Microbiol Infect Dis, 2009; 63(2): 217-22.

18. Jones RN, Stilwell MG, Rhomberg PR, Sader HS. Antipseudomonal activity of piperacillin/ tazo-bactam: more than a decade of experience from the SENTRY Antimicrobial Surveillance Program (1997-2007). Diagn Microbiol Infect Dis, 2009; 65(3): 331-4.

19. Turner PJ. Trends in antimicrobial susceptibilities among bacterial pathogens isolated from patients hospitalized in European medical centers: 6-year report of the MYSTIC Surveillance Study (19972002). Diagn Microbiol Infect Dis, 2005; 51(4): 281-9.

20. Rhomberg PR, Jones RN. Summary trends for the Meropenem Yearly Susceptibility Test Information Collection Program: A 10-year experience in the United States (1999-2008). Diagn Microbiol Infect Dis, 2009; 65(4): 414-26.

21. Nakamura A, Hosoda M, Kato T, Yamada $Y$, Itoh $M$, Kanazawa $\mathrm{K}$ et al. Combined effects of meropenem and aminoglycosides on Pseudomonas aeruginosa in vitro. J Antimicrob Chemother, 2000; 46(6): 901-4.

22. Iseri L, Bayraktar MR. Changes in the percentages of antimicrobial resistance among clinical isolates of Pseudomonas aeruginosa between 2002 and 2004 in a tertiary-care teaching hospital in Turkey. New Microbiol, 2008; 31: 351-5.

23. Zhanel GG, De Corby M, Laing N, Weshnoweski W, Vashisht R, Tailor $\mathrm{F}$ et al. Antimicrobial resistant pathogens in intensive care units in Canada: Results of the Canadian National Intensive Care Unit (CAN-ICU) Study, 2005-2006. Antimicrob Agents Chemother, 2008; 52(4): 1430-7.

24. Eldere JV. Multicentre surveillance of Pseudomonas aeruginosa susceptibility patterns in nosoco $\neg$ mial infections. J Antimicrob Chemother, 2003; 51(2): 347-52.

25. Landman D, Bratu S, Kochar S, Panwar M, Trehan $M$, Doymaz $M$ et al. Evolution of antimicrobial resistance among Pseudomonas aeruginosa, Acinetobacter baumannii and Klebsiella pneumoniae in Brooklyn, NY. J Antimicrob Chemother, 2007; 60(1): 78-82. 
26. Gales AC, Jones RN, Sader HS. Global assessment of antimicrobial activity of polymyxin B against 54731 clinical isolates of gram-negative bacilli: report from the SENTRY antimicrobial surveillance programme (2001-2004). Clin Microbiol Infect, 2006; 12(4): 315-21.

27. Ozdem B, Gürelik FÇ, Celikbilek N, Bıcakcı H, Acıkgöz ZC. Antibiotic resistance profiles of Acinetobacter species isolated from several clinical samples between 2007-2010. Mikrobiyol Bult, 2011; 45(3): 526-34.

28. Kuscu F, Oztürk D, Tütüncü EE, Uslu M, Gürbüz $Y$, Gülen $G$ et al. Evaluation of tigecycline susceptibility by $\mathrm{E}$-Test in multidrug-resistant Acinetobacter baumannii isolates. Klimik J, 2009; 22(2): 48-51.
29. Ozdemir M, Erayman I, Gündem NS, Baykan M, Baysal B. Investigation of antibiotic susceptibility of Acinetobacter strains in nosocomial infections. ANKEM J, 2009; 23(3): 127-32.

30. Cavallo JD, Hocquet D, Plesiat P, Fabre R, RousselDelvallez M. Susceptibility of Pseudomonas aeruginosa to antimicrobials: a 2004 French multicentre hospital study. J Antimicrob Chemother, 2007; 59: 1021-4. 